\title{
PENGUKURAN RISIKO KREDIT DAN PENGUKURAN KINERJA DARI PORTOFOLIO OBLIGASI
}

\author{
Bimbi Ardhana Rizky ${ }^{1}$, Sudarno $^{2}$, Diah Safitri ${ }^{3}$ \\ 1,2,3 Departemen Statistika, Fakultas Sains dan Matematika, Universitas Diponegoro \\ e-mail :dsghani@gmail.com
}

\begin{abstract}
Except getting coupon as a profit, there is loss probability in bond investment that is credit risks investment. One way to measure the credit risk of a bond is to use the credit metrics method. It uses the ratings of the bond issuer company and the transition rating issued by the rating company for its calculations. Mean Variance Efficient Portfolio (MVEP) can be used to make an optimal portfolio so that risk can be obtained to a minimum. An assessment of portfolio performance is needed to increase confidence to invest. Sharpe index can measure portfolio performance based on return value of bond. In this case, study has been conduct in two bonds which are Obligasi Berkelanjutan I Bank BTN Tahap II Tahun 2013 and Obligasi Berkelanjutan I PLN Tahap I Tahun 2013 Seri B. The optimum portfolio formed results 67,96\% proportion for the first bond and 32,04\% for the second bond. For the result, and there is Rp239,4235(billion) of portfolio risk formed. And there is 0,212496for Sharpe index performance assessment portfolio.
\end{abstract}

Keywords: Bond, portfolio, credit risk, credit metrics, Mean Variance Efficient Portfolio, Sharpe index

\section{PENDAHULUAN}

Pasar modal di Indonesia semakin berkembang seiring berjalannya waktu. Di dunia pasar modal, tidak hanya perdagangan saham yang banyak dilakukan tetapi juga obligasi atau biasa dikenal sebagai surat utang. Instrumen obligasi merupakan bagian dari instrumen investasi berpendapatan tetap (fixed income securities) karena keuntungan yang diberikan kepada investor obligasi didasarkan pada tingkat kupon yang telah ditentukan sebelumnya. Melakukan investasi obligasi selain menghasilkan pendapatan juga memberikan potensi risiko investasi. Risiko ini bisa berbentuk kebangkrutan perusahaan (default). Selain itu investor obligasi bisa juga mengalami kerugian akibat nilai pasar dari suatu obligasi turun atau lebih rendah daripada harga beli obligasi tersebut.

Salah satu cara pengukuran risiko kredit obligasi yaitu dengan Credit Metrics yang dikenalkan oleh J.P. Morgan. Credit Metrics adalah alat untuk menilai risiko obligasi akibat perubahan nilai hutang yang disebabkan oleh perubahan kualitas obligasi (perubahan nilai rating). Credit Metrics menyatakan perubahan kualitas obligasi, tidak hanya apabila terjadi default, tetapi juga perubahan upgrade dan downgrade rating obligasi. Metode Credit Metrics menggunakan data rating dan matriks transisi dari perusahaan pemeringkat. Di Indonesia, perusahaan pemeringkat yang terkenal antara lain PEFINDO dan PT Kasnic Credit Rating Indonesia. Rating ini yang nantinya akan dijadikan pertimbangan bagi investor untuk menetapkan pilihannya.

Jika investor ingin menginvestasikan uangnya untuk dua atau lebih perusahaan, maka yang akan dihitung yaitu nilai risiko kredit portofolio obligasi. Analisis portofolio berkenaan dengan keinginan memperoleh sekelompok sekuritas untuk dipegang, diberikan kekayaan oleh setiap sekuritas tersebut. Portofolio dikategorikan efisien apabila memiliki tingkat risiko yang sama, mampu memberikan tingkat keuntungan yang lebih tinggi, atau mampu menghasilkan tingkat keuntungan yang sama, tetapi dengan risiko yang lebih rendah.Sedangkan portofolio optimal merupakan portofolio yang dipilih seorang investor dari sekian banyak pilihan yang ada pada kumpulan portofolio yang efisien. Salah satu cara untuk mendapatkan portofolio yang optimal dan efisien yaitu dengan metode Mean 
Variance Efficient Portfolio (MVEP), dimana setiap obligasi akan dihitung bobot masingmasing, sehingga dapat ditentukan proporsi investasi untuk setiap investasi obligasi.

Selanjutnya, akan dihitung kinerja dari portofolio obligasi. Mengukur kinerja portofolio tidak bisa hanya dilihat dari return-nya saja tetapi juga harus memperhatikan risiko yang akan ditanggung investor. Pada tahun 60-an, beberapa alat ukur Indeks tunggal digunakan untuk mengevaluasi kinerja relatif dari para manajer keuangan. Alat ukur evaluasi kinerja ini tidak menyebutkan bagaimana dan mengapa manajer keuangan dapat memiliki kinerja yang lebih baik maupun lebih buruk dari tolok ukur. Salah satu parameter yang dapat digunakan untuk mengukur kinerja portofolio yang dikembangkan oleh William Sharpe yaituindeks kinerja Sharpe. Indeks kinerja tersebut mengasumsikan adanya hubungan linear antara pengembalian (return) portofolio dengan pengembalian dari beberapa indeks pasar. Model tersebut mendasarkan analisisnya pada return masa lalu untuk memprediksikan return dan risiko masa dating. Software yang digunakan dalam penelitian ini adalah R 3.2.3 dan MS. EXCEL 2013.

\section{TINJAUANPUSTAKA}

\subsection{Obligasi}

Obligasi merupakan surat utang jangka menengah-panjang yang dapat dipindahtangankan, diterbitkan oleh emiten yang akan dibeli oleh investor, dimana pihak issuer wajib membayarkan kupon yang telah disepakati pada periode tertentu yang telah ditentukan dan melunasi nominal/pokok dari surat utang tersebut pada saat jatuh tempo kepada investor (Rahardjo, 2003).

\subsubsection{Karakteristik Obligasi}

a. Nilai penerbitan obligasi

b. Jangka waktu obligasi

c. Tingkat suku bunga

d. Jaminan

\subsubsection{Kategori Obligasi}

(Rahardjo, 2003)
a. Government bonds
b. Corporate bonds
c. Mortgage bonds
d. Municipal bonds

(Zubir, 2012)

\subsubsection{Risiko Investasi Obligasi}
a. Risiko tingkat bunga
b. Risiko gagal bayar
c. Call risk
d. Purchasing power risk
e. Reinvestment risk
f. Liquidity risk

(Zubir, 2012)

\subsubsection{Rating Obligasi}

Kesehatan suatu perusahaan digambarkan oleh peringkat kredit (creditrating). Obligasi sebagai salah satu produk investasi, selain memberikan keuntungan juga berpotensi menimbulkan kerugian atas investasi tersebut. Untuk mengurangi risiko tersebut diperlukan pihak ketiga sebagai penyedia informasi tentang kinerja 
keuangan, manajemen, bisnis, dan kondisi industri emiten obligasi tersebut (Rahardjo, 2003)

\subsection{Credit Metrics}

Credit Metrics adalah alat untuk menilai risiko obligasi akibat perubahan nilai hutang yang disebabkan oleh perubahan kualitas obligor (perubahan nilai rating. Credit Metrics menyatakan perubahan nilai obligasi, tidak hanya apabila terjadi default, tetapi juga perubahan upgrade dan downgrade rating obligasi (Morgan, 1997).

\subsubsection{Risiko Kredit Satu Obligasi}

\section{Langkah 1: Perpindahan Rating Kredit}

Dalam Credit Metrics, risiko tidak hanya berasal dari default, tetapi juga dari perubahan nilai rating naik maupun turun. Dengan demikian, penting untuk tidak hanya memperkirakan probabilitas default, tetapi juga diperkirakan probabilitas perpindahan untuk setiap kemungkinan rating obligasi pada risiko kredit. Jadi default hanya sebagai salah satu kemungkinan yang ada dalam satu periode kredit dari sekarang. Probabilitas perpindahan rating ini disajikan dalam bentuk matriks transisi (Morgan, 1997) seperti pada Tabel

Tabel 2. Transisi Matriks Satu Periode (\%)

\begin{tabular}{|c|c|c|c|c|c|c|c|c|}
\hline \multirow{2}{*}{$\begin{array}{c}\text { Inisial } \\
\text { rating }\end{array}$} & \multicolumn{7}{|c|}{ Rating di akhir periode (\%) } \\
\cline { 2 - 9 } & $\mathrm{AAA}$ & $\mathrm{AA}$ & $\mathrm{A}$ & $\mathrm{BBB}$ & $\mathrm{BB}$ & $\mathrm{B}$ & $\mathrm{CCC}$ & Default \\
\hline $\mathrm{AAA}$ & $p_{A A A, A A A}$ & $p_{A A A, A A}$ & $p_{A A A, A}$ & $p_{A A A, B B B}$ & $p_{A A A, B B}$ & $p_{A A A, B}$ & $p_{A A A, C C C}$ & $p_{A A A, D}$ \\
\hline $\mathrm{AA}$ & $p_{A A, A A A}$ & $p_{A A, A A}$ & $p_{A A, A}$ & $p_{A A, B B B}$ & $p_{A A, B B}$ & $p_{A A, B}$ & $p_{A A, C C C}$ & $p_{A A, D}$ \\
\hline $\mathrm{A}$ & $p_{A, A A A}$ & $p_{A, A A}$ & $p_{A, A}$ & $p_{A, B B B}$ & $p_{A, B B}$ & $p_{A, B}$ & $p_{A, C C C}$ & $p_{A, D}$ \\
\hline $\mathrm{BBB}$ & $p_{B B B, A A A}$ & $p_{B B B, A A}$ & $p_{B B B, A}$ & $p_{B B B, B B B}$ & $p_{B B B, B B}$ & $p_{B B B, B}$ & $p_{B B B, C C C}$ & $p_{B B B, D}$ \\
\hline $\mathrm{BB}$ & $p_{B B, A A A}$ & $p_{B B, A A}$ & $p_{B B, A}$ & $p_{B B, B B B}$ & $p_{B B, B B}$ & $p_{B B, B}$ & $p_{B B, C C C}$ & $p_{B B, D}$ \\
\hline $\mathrm{B}$ & $p_{B, A A A}$ & $p_{B, A A}$ & $p_{B, A}$ & $p_{B, B B B}$ & $p_{B, B B}$ & $p_{B, B}$ & $p_{B, C C C}$ & $p_{B, D}$ \\
\hline $\mathrm{CCC}$ & $p_{C C C, A A A}$ & $p_{C C C, A A}$ & $p_{C C C, A}$ & $p_{C C C, B B B}$ & $p_{C C C, B B}$ & $p_{C C C, B}$ & $p_{C C C, C C C}$ & $p_{C C C, D}$ \\
\hline
\end{tabular}

\section{Langkah 2: Valuation}

1. Penilaian dalam keadaan default

Jika kualitas kredit bermigrasi ke keadaan default, kemungkinan nilai residual dari pelunasan akan tergantung pada kelas senioritas dari utang. Tabel 3 adalah tabel recovery rate berdasarkan kelas senioritas yang diperoleh berdasarkan studi default pada perusahaan penerbit obligasi.

Tabel 3. Recovery Rates Berdasarkan Kelas Senioritas

\begin{tabular}{|c|c|c|}
\hline Kelas senioritas & Mean (\%) & Standar Deviasi (\%) \\
\hline Senior Secured & 53.80 & 26.86 \\
\hline Senior Unsecured & 51.13 & 25.45 \\
\hline Senior Subordinated & 38.52 & 23.81 \\
\hline Subordinated & 32.74 & 20.18 \\
\hline Junior Subordinated & 17.09 & 10.90 \\
\hline
\end{tabular}

Sumber: Carty \& Lieberman [96a] - Moody's Investors Service

Apabila tidak diketahui nilai recovery rate berdasarkan kelas senioritas maka akan dinilai semua valuation dari default obligasi dengan nilai yang sama. Nilai ini dimodelkan dari distribusi uniform, distribusi yang mempunyai variabel acak bernilai 0 sampai dengan 1. Distribusi uniform memiliki nilai mean 0,5 dan standar deviasi $0,29(\sigma=\sqrt{1 / 12})$ 
2. Penilaian dalam keadaan upgradeldowngrade

Untuk mendapatkan valuation pada risiko perpindahan rating naik maupun turun, dapat diperoleh langsung dari penilaian ulang nilai obligasi. Langkah yang dapat dilakukan:

a. Hitung kurva nol maju untuk setiap kategori rating. Kurva maju ini menyatakan risiko obligasi pada saat jatuh tempo.

b. Dengan menggunakan kurva nol, menilai ulang obligasi yang tersisa pada arus kas apabila terjadi risiko perpindahan kualitas kredit untuk masingmasing kategori rating.

Kemudian akan dilakukan penghitungan nilai $v$ (valuation), dengan rumus:

$$
v=c+\frac{c}{\left(1+r_{1}+s_{1}\right)^{1}}+\frac{c}{\left(1+r_{2}+s_{2}\right)^{2}}+\cdots+\frac{c+P}{\left(1+r_{N}+s_{N}\right)^{N}}
$$

dimana:

c : nilai kupon

$s_{i}$ : credit spread dari obligasi pada setiap rating pada tahun ke $\mathrm{i}$

$r_{i}$ : suku bunga bebas risiko pada waktu $\mathrm{T}$ yang diharapkan pada waktu tahun ke-i

$\mathrm{P}$ : harga awal obligasi

$\mathrm{N}$ : banyaknya periode pembayaran kupon - 1

Nilai $v$ ini merupakan nilai obligasi yang mungkin pada satu tahun/periode untuk masing-masing perubahan rating. Sementara untuk faktor pembagi jumlahan antara credit spread dan suku bunga bebas risiko dapat digunakan nilai kurva maju.

\section{Langkah 3: Estimasi risiko kredit}

Menurut Morgan (1997), dalam melakukan estimasi untuk risiko kredit digunakan dua ukuran. Kedua ukuran ini adalah standar deviasi dan level persentil.

Standar deviasi

$$
\begin{aligned}
\mu_{\text {Total }} & =\sum_{i=1}^{s} p_{i} v_{i} \\
\sigma_{\text {Total }} & =\sqrt{\sum_{i=1}^{s} p_{i} v_{i}^{2}-\mu_{\text {Total }}^{2}}
\end{aligned}
$$

dimana:

vi :value nilai obligasi yang mungkin pada satu periode untuk perubahan rating ke-i

$p_{i} \quad$ : probabilitas atau likelihood pada state i di akhir periode

$s \quad$ : banyaknya kategori rating

$\mu_{\text {Total }} \quad$ : mean total

$\sigma_{\text {Total }} \quad$ : standar deviasi total

Tingkat persentil pertama dapat diambil dari beberapa titik yang telah ditentukan sebelumnya misalnya $1 \%$ atau $5 \%$, akan dilihat pada rating mana jumlah kumulatif probabilitasnya tepat lebih dari $1 \%$ dihitung mulai dariprobabilitas default sampai pada rating tertinggi. Nilai pada rating tersebut akan diambil sebagai persentil level pertama. 


\subsubsection{Risiko Kredit Satu Obligasi}

Setelah dilakukan valuation untuk kedua obligasi, yaitu dengan langkah seperti pada satu obligasi, maka akan dijumlahkan nilai valuation kedua obligasi sehingga terbentuk matriks valuation dua obligasi. Selanjutnya, akan ditentukan join matriks transisi untuk kedua obligasi.

Matriks peluang transisi bersamaadalah perkalian antara probabilitas matriks perpindahan rating kedua obligasi, yaitu:

$$
\boldsymbol{M}=\boldsymbol{G}_{1}{ }^{T} \boldsymbol{G}_{2}
$$

dimana:

$\boldsymbol{M}$ : matriks peluang transisi bersama
$\boldsymbol{G}_{\boldsymbol{1}}$ : matriks peluang transisi rating obligasi 1
$\boldsymbol{G}_{2}$ :matriks peluang transisi rating obligasi 2

Tabel 4. Valuation Portofolio Dua Obligasi

\begin{tabular}{|c|c|c|c|c|c|c|}
\hline \multirow{2}{*}{$\begin{array}{c}\text { Rating } \\
\text { Obligasi 1 }\end{array}$} & & \multicolumn{5}{|c|}{ Rating Obligasi 2} \\
\cline { 3 - 7 } & Valuation & AAA & AA & $\mathrm{A}$ & $\cdots$ & Default \\
\hline & $v_{2, A A A}$ & $v_{2, A A}$ & $v_{2, A}$ & $\cdots$ & $v_{2, D}$ \\
\hline AAA & $v_{1, A A A}$ & $v_{1, A A A}+v_{2, A A A}$ & $v_{1, A A A}+v_{2, A A}$ & $v_{1, A A A}+v_{2, A}$ & $\ldots$ & $v_{1, A A A}+v_{2, D}$ \\
\hline $\mathrm{AA}$ & $v_{1, A A}$ & $v_{1, A A}+v_{2, A A A}$ & $v_{1, A A}+v_{2, A A}$ & $v_{1, A A}+v_{2, A}$ & $\ldots$ & $v_{1, A A}+v_{2, D}$ \\
\hline $\mathrm{A}$ & $v_{1, A}$ & $v_{1, A}+v_{2, A A A}$ & $v_{1, A}+v_{2, A A}$ & $v_{1, A}+v_{2, A}$ & $\ldots$ & $v_{1, A}+v_{2, D}$ \\
\hline$\vdots$ & $\vdots$ & $\vdots$ & $\vdots$ & $\vdots$ & $\ddots$ & $\vdots$ \\
\hline Default & $v_{1, D}$ & $v_{1, D}+v_{2, A A A}$ & $v_{1, D}+v_{2, A A}$ & $v_{1, D}+v_{2, A}$ & $\cdots$ & $v_{1, D}+v_{2, D}$ \\
\hline
\end{tabular}

(Morgan, 1997)

\subsection{Mean Variance Efficient Portfolio (MVEP)}

Menurut Maruddani dan Purbowati (2009), Mean Variance Efficient Portfolio (MVEP) merupakan salah satu metode dalam pembentukan portofolio optimal.Hal tersebut sama dengan mengoptimasi bobot $\boldsymbol{w}=\left[w_{1} \ldots w_{N}\right]^{T}$ berdasarkan maksimum mean risiko dari varian yang diberikan. Secara lebih formal, dicari vektor pembobotan $\boldsymbol{w}$ agar portofolio yang dibentuk mempunyai varian yang minimum berdasarkan dua batasanyaitu:

1. Spesifikasi awal dari mean risiko $\mu_{p}$ harus tercapai yaitu $\boldsymbol{w}^{T} \boldsymbol{\mu}$.

2. Jumlah proporsi dari portofolio yang terbentuk sama dengan 1 yaitu $\boldsymbol{w}^{T} \mathbf{1}_{N}=1$, dimana $\mathbf{1}_{N}$ adalah vektor satuan dengan dimensi $\mathrm{N}$ x 1 .

Permasalahan optimalisasi dapat diselesaikan dengan fungsi Lagrange yaitu:

$$
L=w^{T} \sum w+\lambda_{1}\left(\mu_{p}-w^{T} \mu\right)+\lambda_{2}\left(1-w^{T} \mathbf{1}_{N}\right)
$$

dengan, $L$ : fungsi Lagrange

\section{$\lambda$ : faktor pengali Lagrange} wyaitu:

Untuk mendapatkan nilai optimal $\boldsymbol{w}$, persamaan diatas diturunkan parsial terhadap

$$
\begin{gathered}
\frac{\partial L}{\partial \boldsymbol{w}}=0 \\
\frac{\partial}{\partial \boldsymbol{w}}\left[\boldsymbol{w}^{T} \sum \boldsymbol{w}+\lambda_{1}\left(\mu_{p}-\boldsymbol{w}^{T} \boldsymbol{\mu}\right)+\lambda_{2}\left(1-\boldsymbol{w}^{T} \mathbf{1}_{N}\right)\right]=0
\end{gathered}
$$

Maka diperoleh persamaan pembobotan pada MVEPadalah:

$\operatorname{dimana} \boldsymbol{S}^{-1}$ : invers matriks varian-kovarian.

$$
\boldsymbol{w}=\frac{\sum^{-\mathbf{1}} \mathbf{1}_{N}}{\mathbf{1}_{N}^{T} \sum^{-\mathbf{1}} \mathbf{1}_{N}}
$$

Turunan kedua fungsi Lagrange terhadap bobot merupakan syarat mencapai minimum: 
Dimana $2 \sum$ merupakan matriks definit positif.

$$
\frac{\partial^{2} L}{\partial \boldsymbol{w}^{2}}=2 \Sigma
$$

\subsection{Indeks Kinerja Sharpe}

Menurut Manurung (2007), salah satu metode yang digunakan untuk membandingkan kinerja portofolio dengan menggunakan konsep dari Garis Pasar Modal/ Capital Market Line (CML). Dimana Sharpe menyatakan series kinerja portofolio dihitung merupakan hasil bersih dari portofolio dengan tingkat bunga bebas risiko per unit risiko dengan diberi simbol $S p$. Indeks kinerja Sharpe dihitung dengan formula sebagai berikut:

$$
S_{p}=\frac{R_{p}-R_{f}}{\sigma_{p}}
$$

dimana:

$S_{p}:$ Indeks kinerja Sharpe

$R_{p}:$ return portofolio

$R_{f}$ : return bebas risiko

dimana:

$\sigma_{p}:$ standar deviasi portofolio

$$
R_{p}=\sum_{t=1}^{n}\left(w_{t} \cdot R_{t}\right)
$$

dengan:

$w_{t}$ : porsi dari obligasi ke-t terhadap seluruh obligasi di portofolio

$R_{t}:$ return dari obligasi ke-t

$\mathrm{n}$ : banyaknya obligasi

Dalam hal ini, return bebas risiko $\left(R_{f}\right)$ diperoleh dari Sertifikat Bank Indonesia (SBI) yang diterbitkan oleh Bank Indonesia.

\section{METODE PENELITIAN}

\subsection{Sumber Data dan Variabel Penelitian}

Data yang digunakan pada tugas akhir ini adalah data obligasi yang diterbitkan dua perusahaan finance yang dipublikasikan oleh perusahaan pemeringkat obligasi IBPA (Indonesia Bond Pricing Agency) dan data closing price masing-masing obligasi yang diperoleh dari PT Indonesian Capital Market Electronic Library (ICaMEL). Obligasi pertama yaitu Obligasi Berkelanjutan I Bank BTN Tahap II Tahun 2013 dan obligasi kedua yaitu Obligasi Berkelanjutan I PLN Tahap I Tahun 2013 Seri B.

\subsection{Variabel Penelitian}

1. Data Obligasi berupa harga obligasi, kupon, tahun terbit, dan jatuh tempo

2. Rating Obligasi Perusahaan

3. Nilai Closing Price Obligasi periode Juni 2014 - Desember 2017

4. Tingkat suku bunga dari laporan Sertifikat Bank Indonesia (SBI) periode Juni 2014 - Desember 2017

\subsection{Tahapan Analisis Data}

1. Input data nominal obligasi, kupon obligasi, rating obligasi, matriks transisi dari badan pemeringkat rating, return masing-masing obligasi, serta return SBI.

2. Mencari matriks transisi lima periode

3. Mencari nilai valuation masing-masing obligasi berdasarkan nominal obligasi dan kupon obligasi yang disesuaikan dengan rating dari obligasi tersebut.

4. Mencari matriks transisi bersama dari portofolio obligasi. 
5. Mencari pembobotan untuk memperoleh risiko yang minimum dengan menggunakan metode Mean Variance Portofolio (MVEP).

6. Mencari valuation portofolio sehingga bisa dicari risiko kredit portofolio dengan Credit Metrics.

7. Selanjutnya akan dihitung kinerja portofolio obligasi menggunakan Indeks kinerja Sharpe.

\section{HASIL DAN PEMBAHASAN}

Data yang akan digunakan dalam tugas akhir ini adalah data obligasi yang diterbitkan oleh perusahaan pemeringkat obligasi IBPA (Indonesia Bond Pricing Agency). Detail data akan ditampilkan pada Tabel 5.

Tabel 5. Detail Obligasi

\begin{tabular}{|c|c|c|}
\hline Jenis & Obligasi I & Obligasi II \\
\hline Perusahaan & $\begin{array}{c}\text { PT. Bank Tabungan } \\
\text { Negara Tbk }\end{array}$ & $\begin{array}{c}\text { PT. Perusahaan Listrik } \\
\text { Negara }\end{array}$ \\
\hline Nama Obligasi & $\begin{array}{c}\text { Obligasi Berkelanjutan I } \\
\text { Bank BTN Tahap II } \\
\text { Tahun 2013 }\end{array}$ & $\begin{array}{c}\text { Obligasi Berkelanjutan I } \\
\text { PLN Tahap I Tahun } \\
\text { 2013 Seri B }\end{array}$ \\
\hline Nominal Terbitan & Rp2.000.000.000.000,00 & Rp697.000.000.000,00 \\
\hline Kupon & $7,90 \%$ & $8,25 \%$ \\
\hline $\begin{array}{c}\text { Jangka Waktu } \\
\text { Pembayaran Kupon }\end{array}$ & 3 bulan & 5 Julan 2013 \\
\hline Tanggal diterbitkan & 27 Maret 2013 & 5 Oktober 2013 \\
\hline $\begin{array}{c}\text { Pembayaran Kupon } \\
\text { Pertama }\end{array}$ & 27 Juni 2013 & 5 Juli 2023 \\
\hline Tanggal Jatuh Tempo & 27 Maret 2023 & \\
\hline
\end{tabular}

\subsection{Mencari Matriks Transisi Lima Periode}

Matriks transisi dan kurva maju yang digunakan berasaldari 2015 Corporate Default and Rating Transition Study yang diterbitkan oleh perusahaan pemeringkat PT. PEFINDO. Data ini adalah data histori perpindahan rating perusahaan-perusahaan penerbit obligasi dari berpuluh tahun sebelumnya, sehingga dibentuklah matriks transisi seperti Tabel 6.

Tabel 6. Rating Transisi PT. PEFINDO (1996-2015)

\begin{tabular}{|c|c|c|c|c|c|c|c|c|c|}
\hline \multirow{2}{*}{$\begin{array}{c}\text { Rating } \\
\text { awal }\end{array}$} & \multicolumn{10}{|c|}{ Rating di akhir periode $(\%)$} \\
\cline { 2 - 11 } & idAAA & idAA & idA & idBBB & idBB & idB & idCCC & idD & $N R$ \\
\hline idAAA & 96,70 & 1,10 & 1,10 & 0,00 & 0,00 & 0,00 & 0,00 & 0,00 & 1,10 \\
\hline idAA & 5,54 & 88,24 & 3,81 & 0,00 & 0,69 & 0,00 & 0,00 & 1,04 & 0,69 \\
\hline idA & 0,31 & 7,72 & 84,57 & 3,24 & 0,62 & 0,00 & 0,00 & 2,47 & 1,08 \\
\hline idBBB & 0,00 & 0,69 & 16,36 & 64,89 & 3,46 & 1,15 & 1,38 & 9,22 & 2,76 \\
\hline idBB & 0,00 & 0,00 & 6,94 & 20,78 & 19,48 & 5,19 & 3,90 & 29,87 & 14,29 \\
\hline idB & 0,00 & 0,00 & 0,00 & 13,04 & 13,04 & 26,09 & 4,35 & 30,43 & 13,04 \\
\hline idCCC & 0,00 & 0,00 & 0,00 & 0,00 & 0,00 & 14,29 & 0,00 & 57,14 & 28,57 \\
\hline
\end{tabular}

Sumber: PT. PEFINDO

Matriks transisi satu periode digunakan ketika tanggal jatuh tempo terhitung satu tahun dari tahun perhitungan, misalkan untuk menentukan perhitungan nilai risiko obligasi yang jatuh tempo pada tahun 2019maka perhitungan pada tahun 2018 menggunakan 
matriks satu periode yaitu dengan matriks $\mathbf{P}^{\mathbf{1}}$. Matriks transisi lima periode didapatkan dengan menggunakan matrik transisi $\mathbf{P}^{\mathbf{t}}$ t-langkah, dalam hal ini dengan nilai lima periode, dari obligasi yang jatuh tempo pada tahun 2023 maka perhitungan pada tahun 2018 menggunakan matriks transisi $\mathbf{P}^{\mathbf{5}}$ dengan $\mathbf{P}$ adalah matriks transisi satu periode. Sehingga didapatkan matriks transisi lima periode sesuai pada Tabel 8.

Tabel 8. Rating Transisi Lima Periode hingga Peluang Default

\begin{tabular}{|c|c|c|c|c|c|c|c|c|}
\hline \multirow{2}{*}{$\begin{array}{c}\text { Rating } \\
\text { awal }\end{array}$} & \multicolumn{7}{|c|}{ Rating di akhir periode $(\%)$} \\
\cline { 2 - 9 } & idAAA & idAA & idA & idBBB & idBB & idB & idCCC & idD \\
\hline idAAA & 85,13 & 4,69 & 4,13 & 0,23 & 0,06 & 0,01 & 0,00 & 0,16 \\
\hline idAA & 20,59 & 55,98 & 11,58 & 1,02 & 0,67 & 0,07 & 0,04 & 1,23 \\
\hline idA & 4,21 & 22,18 & 48,05 & 5,86 & 0,88 & 0,17 & 0,12 & 2,49 \\
\hline idBBB & 1,02 & 7,84 & 28,54 & 15,15 & 1,44 & 0,65 & 0,40 & 3,89 \\
\hline idBB & 0,38 & 3,20 & 12,77 & 7,28 & 0,77 & 0,42 & 0,22 & 2,04 \\
\hline idB & 0,12 & 1,35 & 7,29 & 6,46 & 0,78 & 0,54 & 0,23 & 2,00 \\
\hline idCCC & 0,01 & 0,12 & 0,96 & 1,28 & 0,20 & 0,17 & 0,06 & 0,49 \\
\hline idD & 0,00 & 0,00 & 0,00 & 0,00 & 0,00 & 0,00 & 0,00 & 0,00 \\
\hline
\end{tabular}

\subsection{Mencari Valuation dari Masing-masing Obligasi}

Akan digunakan Software R 3.2.3 untuk menghitung valuation dari kedua obligasi dengan menginputkan data yang diperoleh dari perusahaan pemeringkat berupa nilai kupon, nominal obligasi, matriks transisi serta kurva maju, maka akan diperoleh nilai valuation untuk kedua obligasi yang dapat dilihat pada Tabel dan Tabel

Tabel 9. Valuation Obligasi Berkelanjutan I Bank BTN Tahap II Tahun 2013

\begin{tabular}{|c|c|}
\hline Rating & Valuation (Rp (Milyar)) \\
\hline idAAA & 3580,0000 \\
\hline idAA & 3357,7405 \\
\hline idA & 2210,8549 \\
\hline idBBB & 1161,3169 \\
\hline idBB & 557,6379 \\
\hline idB & 359,9787 \\
\hline idCCC & 230,6076 \\
\hline idD & 1000,0000 \\
\hline
\end{tabular}

Tabel 10. Valuation Obligasi Berkelanjutan I PLN Tahap I Tahun 2013 Seri B

\begin{tabular}{|c|c|}
\hline Rating & Valuation (Rp (Milyar)) \\
\hline idAAA & 1272,02500 \\
\hline idAA & 1193,49559 \\
\hline idA & 788,75723 \\
\hline idBBB & 416,81460 \\
\hline idBB & 201,93406 \\
\hline idB & 130,69448 \\
\hline idCCC & 83,77294 \\
\hline idD & 348,5000 \\
\hline
\end{tabular}

\subsection{Mencari Matriks Joint Probability dari Kedua Obligasi}

Untuk mencari matriksjoint probability, akan digunakan Ms. Excel 2013 dengan menggunakan persamaan, sehingga:

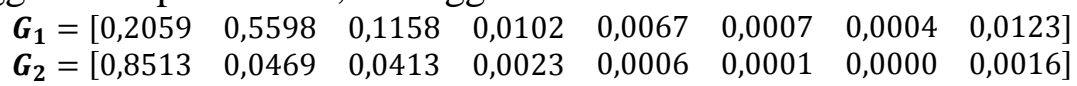




$$
\begin{aligned}
& M=G_{1}^{T} G_{2} \\
& \boldsymbol{M}=\left[\begin{array}{l}
0,2059 \\
0,5598 \\
0,1158 \\
0,0102 \\
0,0067 \\
0,0007 \\
0,0004 \\
0,0123
\end{array}\right] x\left[\begin{array}{llllllll}
0,8513 & 0,0469 & 0,0413 & 0,0023 & 0,0006 & 0,0001 & 0,0000 & 0,0016
\end{array}\right] \\
& =\left[\begin{array}{llllllll}
0,17526 & 0,00966 & 0,00850 & 0,00047 & 0,00013 & 0,00001 & 0,00001 & 0,00033 \\
0,47657 & 0,02627 & 0,02312 & 0,00128 & 0,00036 & 0,00003 & 0,00002 & 0,00089 \\
0,09855 & 0,00543 & 0,00478 & 0,00026 & 0,00007 & 0,00001 & 0,00000 & 0,00018 \\
0,00868 & 0,00048 & 0,00042 & 0,00002 & 0,00001 & 0,00000 & 0,00000 & 0,00002 \\
0,00569 & 0,00031 & 0,00028 & 0,00002 & 0,00000 & 0,00000 & 0,00000 & 0,00001 \\
0,00058 & 0,00003 & 0,00003 & 0,00000 & 0,00000 & 0,00000 & 0,00000 & 0,00000 \\
0,00035 & 0,00002 & 0,00002 & 0,00000 & 0,00000 & 0,00000 & 0,00000 & 0,00000 \\
0,01050 & 0,00058 & 0,00051 & 0,00003 & 0,00001 & 0,00000 & 0,00000 & 0,00002
\end{array}\right]
\end{aligned}
$$

\subsection{Mencari Bobot Optimal dengan MVEP}

Setiap investor pastinya ingin modal yang ditanamkan pada obligasi memiliki risiko rendah dengan pendapatan yang tinggi. Maka dari itu, akan dibentuk suatu portofolio yang optimal dan efisien dengan menggunakan Mean Variance Efficient Portfolio (MVEP). Untuk mencari bobot optimal, sebelumnya akan dibentuk matriks varian-kovarian dari risiko obligasi dengan matriks mean dan matriks standar deviasi dengan perhitungan menggunakan Software R, diperoleh bobot untuk masing-masing obligasi:

$$
\begin{gathered}
\boldsymbol{w}=\frac{\sum^{-\mathbf{1}} \mathbf{1}_{2}}{\mathbf{1}_{2}^{T} \sum^{-\mathbf{1}} \mathbf{1}_{2}} \\
{\left[\begin{array}{l}
w_{1} \\
w_{2}
\end{array}\right]=\left[\begin{array}{l}
0,6796 \\
0,3204
\end{array}\right]}
\end{gathered}
$$

dimana:

$w_{1}$ :bobotObligasi Berkelanjutan I Bank BTN Tahap II Tahun 2013

$w_{2}$ :bobotObligasi Berkelanjutan I PLN Tahap I Tahun 2013 Seri B

\begin{tabular}{|c|c|c|c|c|c|c|c|c|c|}
\hline \multirow{3}{*}{ Obligasi 1} & \multicolumn{9}{|c|}{ Obligasi 2} \\
\hline & & idAAA & idAA & idA & idBBB & idBB & $\mathrm{idB}$ & idCCC & idD \\
\hline & Valuation & 1272,0250 & 1193,4956 & 788,7572 & 416,8146 & 201,9341 & 130,6945 & 83,7729 & 348,5000 \\
\hline idAAA & 3580,0000 & 2840,525 & 2815,364 & 2685,686 & 2566,515 & 2497,668 & 2474,843 & 2459,809 & 2544,627 \\
\hline idAA & 3357,4828 & 2689,302 & 2664,141 & 2534,463 & 2415,293 & 2346,445 & 2323,62 & 2308,586 & 2393,405 \\
\hline idA & 2210,9883 & 1910,144 & 1884,984 & 1755,305 & 1636,135 & 1567,287 & 1544,462 & 1529,429 & 1614,247 \\
\hline idBBB & 1161,1529 & 1196,676 & 1171,516 & 1041,837 & 922,6669 & 853,8192 & 830,9941 & 815,9604 & 900,7789 \\
\hline idBB & 557,3143 & 786,3076 & 761,1468 & 631,4686 & 512,2982 & 443,4505 & 420,6253 & 405,5917 & 490,4102 \\
\hline $\mathrm{idB}$ & 359,6680 & 651,9872 & 626,8263 & 497,1482 & 377,9778 & 309,13 & 286,3049 & 271,2712 & 356,0898 \\
\hline idCCC & 230,2364 & 564,0254 & 538,8646 & 409,1864 & 290,016 & 221,1683 & 198,3431 & 183,3095 & 268,128 \\
\hline idD & 1000,0000 & 1087,157 & 1061,996 & 932,3178 & 813,1474 & 744,2997 & 721,4745 & 706,4408 & 791,2594 \\
\hline
\end{tabular}

\subsection{Mencari Valuation Portofolio Obligasi}

Dari output Software R 3.2.3 diperoleh nilai valuation untuk kedua obligasi seperti pada Tabel.

Tabel 11. Valuation untuk Portofolio Dua Obligasi

\subsection{Menghitung Kinerja Portofolio Obligasi dengan Indeks Sharpe}

Untuk mendapatkan Indeks kinerja Sharpe hal yang harus dilakukan yaitu menghitung return masing-masing obligasi dari closing price bulanan masing-masing obligasi serta nilai Sertifikat Bank Indonesia (SBI) menggunakan rumus: 


$$
R_{t}=\ln \left(\frac{P_{t}}{P_{t-1}}\right)
$$

berikut:

Selanjutnya akan dihitung indeks kinerja Sharpe menggunakan rumus sebagai

$$
\begin{gathered}
S_{p}=\frac{R_{p}-R_{f}}{\sigma_{p}} \\
\text { dimana: } R_{p}=\sum_{t=1}^{n}\left(w_{t} \cdot R_{t}\right) \text { dan }\left[\begin{array}{l}
w_{1} \\
w_{2}
\end{array}\right]=\left[\begin{array}{l}
0,6796 \\
0,3204
\end{array}\right]
\end{gathered}
$$

sehingga:

$$
\begin{aligned}
S_{p} & =\frac{0,003019-(-0,007503)}{0,050321} \\
& =0,212496
\end{aligned}
$$

\section{KESIMPULAN}

Berdasarkan hasil dan pembahasan diperoleh kesimpulan sebagai berikut :

1. Berdasarkan perhitungan pada kedua obligasi perusahaan didapatkan bahwa portofolio obligasi yang terdiri dari Obligasi Berkelanjutan I Bank BTN Tahap II Tahun 2013 memiliki rating idAA serta Obligasi Berkelanjutan I PLN Tahap I Tahun 2013 Seri B memiliki rating idAAA, memiliki risiko portofolio sebesar Rp240,708(Milyar) dengan mean sebesar Rp22,57495(Milyar).

2. Bobot yang diberikan untuk masing-masing obligasi adalah $67,96 \%$ untuk Obligasi Berkelanjutan I Bank BTN Tahap II Tahun 2013 dan 32,04\% untuk Obligasi Berkelanjutan I PLN Tahap I Tahun 2013 Seri B, agar diperoleh portofolio obligasi yang optimal dengan risiko yang minimum.

3. Nilai return dari kedua obligasi menghasilkan indeks kinerja Sharpe sebesar 0,212496, sehingga portofolio yang terdiri dari Obligasi Berkelanjutan I Bank BTN Tahap II Tahun 2013 dan Obligasi Berkelanjutan I PLN Tahap I Tahun 2013 Seri B mempunyai kinerja positif, yang berarti baik.

\section{DAFTAR PUSTAKA}

Elton, E.J., Grubber. 1977. Risk Reduction and Portofolio Size: An Analytical Solution. Journal of Business. Vol.50 Oktober hal.415-437.

Hanafi, M. 2014. Manajemen Risiko. Yogyakarta: BPFE.

IBPA. 2017. Info Detail Obligasi. http://www.ibpa.co.id/DataPasarSuratUtang/BondGovernmentDetail/tabid/114/Defa ult.aspx?bondId=BCAF02BCN2 [8 Januari 2018]

IBPA. 2017. Info Detail Obligasi.

http://www.ibpa.co.id/DataPasarSuratUtang/BondGovernmentDetail/tabid/114/Defa ult.aspx?bondId=BIIF01ACN3 [8 Januari 2018]

Iqbal, M.H. 2002. Pokok-pokok Materi Statistik I (Statistik Deskriptif). Jakarta: PT. Bumi Aksara.

Manurung, A.H. 2007. Pengelolaan Portofolio Obligasi. Jakarta: PT. Elex Media Komputindo.

Maruddani, D.A.I., dan Purbowati, A. 2009. Pengukuran Value at Risk pada Aset Tunggal dan Portofolio dengan Simulasi Monte Carlo. Media Statistika Vol. 2, No. 2: Hal. 93-104.

Morgan, J.P. 1997. Credit Metrics - Technical Document. New York: J.P Morgan \& Co. Incorporated. 
Rahardjo, S. 2003. Panduan Investasi Obligasi. Jakarta: PT. Gramedia Pustaka Utama. Ross, S.M. 1996. Stochastic Process, $2^{\text {nd }}$ Edition. New York: John Willey \& Sons.

Samsul, M. 2006. Pasar Modal dan Manajemen Portofolio. Erlangga: Jakarta.

Sharpe, W.F. 1995. Risk, Market Sensitivy and Diversification. Financial Analysist Journal. Januari-Februari, Hal. 84-88.

Spiegel, M.R. 1996. Teori dan Soal-soal Statistika, Seri Buku Schaum, Edisi kedua. Jakarta: Penerbit Erlangga.

Statman, M. 1987. How Many Stocks Make a Diversified Portofolio.Journal ofFinancial and Quantitative Analysis. Vol.22 no.2 September hlm.353-363.

Sumariyah. 1997. Pengantar Pengetahuan Pasar ModalIndonesia. UUP AMP YKPN: Yogyakarta.

Tandelilin, E. 2001. Analisis Investasi dan Manajemen Portofolio. BPFE:Yogyakarta.

Zubir, Z. 2012. Portofolio Obligasi. Jakarta: Salemba Empat. 